\title{
Mathematics Teaching Efficacy: Differences in Beliefs of Preservice and In-Service Teachers
}

\author{
Hildegardis Mulu ${ }^{1}$, Valeria Suryani Kurnila ${ }^{2}$, Gabariela Purnama Ningsi ${ }^{3}$ \\ Mathematics Education Program, Universitas Katolik Indonesia Santu Paulus Ruteng \\ \{hildamulu93@gmail.com\}
}

\begin{abstract}
This research aimed to obtain a comprehensive picture of the teaching efficacy beliefs of student-teacher candidates (preservice teachers) and mathematics teachers (inservice teachers) and identify the factors that can cause the formation of such beliefs. The participants involved in the study were from two groups. The first group was the math teacher candidates who attended a mathematics teacher education program at a private university; the second group was the same program alumni working as math teachers in secondary schools. This research was mixed-method research that combines quantitative through online questionnaires and qualitative methods through interviews. The instruments used in the study consists of the Mathematics Teaching Efficacy Beliefs Instruments (MTEBI) and interview guidelines. The data were analyzed with descriptive statistics and t-test, whereas the interview data were analyzed with the Miles and Huberman technique. The results showed that the mathematics teaching efficacy beliefs of the preservice and inservice teachers are majorly firm or high in level, with no significant difference between groups. The key factors affecting the formation of such teaching efficacy beliefs are the teacher's mastery of content knowledge during the teacher preparation program and teaching experience.
\end{abstract}

Keywords: mathematics teaching efficacy; belief, preservice teachers; in-service teachers

\section{Introduction}

Research on teaching efficacy has been started for a long time, along with developing the concept of self-efficacy in learning in schools. Initially, the focus of research related to selfefficacy was regarding the level of self-efficacy of students who were subjects in the learning process. However, entering the early 2000s, there was a change with the initiation of several studies related to teacher self-efficacy, who are also essential parties in the learning process. In particular, regarding mathematics teaching efficacy, research related to this topic was recorded starting in 2001 [1].

Tschannen-Moran \& Hoy [2] defines teaching efficacy as "a judgment of his or her capabilities to bring desired outcomes of student engagement and learning, even among those students who may be difficult or unmotivated" (p. 45). Mathematics teaching efficacy can be defined as the teacher's belief in their capability to carry out mathematics learning, improving student learning outcomes, even if they are not motivated to learn. Research shows that a high teaching efficacy belief can predict teacher effectiveness and innovativeness in implementing classroom learning [2]. The most widely conducted research on teaching efficacy was to measure the level of efficacy of pre-service teachers. 
The study conducted by Wenner [1] comprising three other studies in the early 2000s compared the efficacy between the pre-service and practicing math teachers which focused on the factors affecting the beliefs. Over a decade later, there has been a shift in relation to the subject of the study. Teachers (in-service teachers) do not seem to be the main concern for most of the recent studies in teaching efficacy. Most of these studies aim to evaluate teacher education programs implemented and provide recommendations for improving these programs in the future. Only a few research have been done that involve practicing or in-service math teachers in recent years as well as identifying contributing factors of the beliefs (see, for example, Pardimin [6]; Rahayu, Sartono, \& Miftakhuddin [10]; Unsal, Korkmaz, \& Percin [11]). These studies mostly aim to measure the math teachers' level of efficacy in teaching mathematics.

For this reason, researchers feel the need to conduct an internal study of the teaching efficacy belief of prospective mathematics teacher students at UNIKA Santu Paulus Ruteng and to compare with the alumni of the program who have worked as math teachers. In addition, the mathematics teacher subject group was also drawn from the alumni of the mathematics education study program of UNIKA Santu Paulus Ruteng. This research aims to obtain a comprehensive picture of the teaching efficacy beliefs of student-teacher candidates (preservice teachers) and mathematics teachers (in-service teachers) and identify the factors that can cause the formation of such beliefs. A study about the teaching efficacy is necessary to determine the difference in levels between the groups and analyse the causative factors if there is a difference. The research results are expected to be used as material for internal evaluation and enrich the studies related to mathematics teaching efficacy.

\section{Research Methods}

\subsection{Participants}

This study aimed to get a comprehensive picture of the teaching efficacy beliefs of preservice and in-service mathematics teachers, comparing the possible differences between the two groups and identifying the factors that can cause the formation of such beliefs. Hence, the participants involved in the study were classified into two groups. The first group was the math teacher candidates who are currently attending a teacher education program in their fourth year. Meanwhile, the second group was the alumni of the same program who are now working as math teachers in secondary schools. The first group consists of 35 participants, while another 18 math teachers make up the second group.

In determining the participants, some key factors are considered to serve the purpose of the study. Firstly, the preservice teachers are in their fourth year of the program and have completed most of the modules. They have also engaged in a teacher practising program in secondary schools for about two months ( 8 weeks). This program allows them to experience, though limited in time, how to become professional math teachers.

On the other hand, selecting the 18 math teachers who have attended the teacher preparation program from the same institution as the teacher candidates was purposely done to minimise the beliefs' external factors. It is assumed that different institutions might have different approaches in their teacher preparation programs, consequently affecting the program's learning outcomes. Thus, it is anticipated by having the alumni participate in the study as the second group. These in-service teachers have varied experience in teaching secondary schools, both junior and senior high schools, ranging from less than one year to up to 5 years. 


\subsection{Procedure}

As mentioned earlier, this study aimed to gather information on the teaching efficacy beliefs of preservice and in-service mathematics teachers, find out whether there are differences in beliefs between the groups, and identify the factors influencing the formation of such beliefs. Hence, this research is mixed-method research that combines quantitative and qualitative methods. The use of quantitative methods is through an online questionnaire technique which contains a list of statements related to mathematics teaching efficacy belief. These questions are taken from the Mathematics Teaching Efficacy Belief Instrument (MTEBI), a standardised instrument developed by Enochs and Riggs [2]. The survey technique was used to get an idea of the level of teaching efficacy belief in the two groups of respondents. The online questionnaire was delivered before the focused group interview. Both preservice and in-service teachers' groups were required to answer the questionnaire items, including the demographic questions.

Furthermore, semi-structured interviews were conducted with ten respondents (five from each group) selected purposely to represent each group (preservice and in-service teachers with high, moderate, and low efficacy levels). Interviews were conducted to identify the factors that influence the mathematics teaching efficacy belief of the subjects. The interviews were done separately between the preservice and in-service teachers.

\subsection{Instruments}

The instruments used in the study consists of the Mathematics Teaching Efficacy Beliefs Instruments (MTEBI) and a follow-up list of questions for the interview. The MTEBI instrument was initially developed by Enoch and Riggs [3] with the original 23 items. It is an instrument to measure the degree to which preservice and in-service teachers feel that they teach mathematics effectively. In this study, the version used is the 21-items revised by Ryang [3] in his Korean translation version. By prioritising the similarity in meaning and ensuring cultural appropriateness, the 21 -items were then translated into Indonesian for use in this study. The process of translation is done by considering the context of the learning process and curriculum in Indonesian secondary schools.

Hence, some of the contexts which are slightly different are modified to fit the Indonesian classroom context. The instrument consists of two subscales, i.e. Personal Mathematics Teaching Efficacy (PMTE) and Mathematics Teaching Outcome Expectancy (MTOE). Among the items, 13 items are of PMTE, which describes personal beliefs about one's ability to teach mathematics effectively; and eight items are MTOE describing the expectancy that effective mathematics teaching will result in a positive outcome in students' mathematical learning [3].

The instrument used the Likert scale with five-scale options, ranging from strongly agree to strongly disagree. The wording of the items for both pre-service and in-service teachers differ in the tenses used, mainly future tense for the preservice teachers since they have not become professional teachers yet. Eight PMTE items were negatively worded, while all the MTOE items were all positively framed. The questionnaire also included demographic questions, including gender, age, years of teaching experience, and workplace for in-service teachers. The purpose is to gather information about the subjects' backgrounds.

\subsection{Data Analysis}

The analysis of the questionnaire results was carried out using descriptive and inferential statistics. The descriptive statistics describe the mean and standard deviation of each group's mathematics teaching efficacy belief and categorise them into high, moderate, and low levels. Furthermore, the inferential process is conducted by performing a t-test to determine whether 
there is a significant difference in teaching efficacy beliefs between the two subjects. For qualitative data analysis consequently affecting this study used the technique with model interactive analysis of Miles and Huberman. The three components of the research are data reduction, presentation of data, and drawing conclusions or verification. In the process of data reduction, a thematic analysis was also carried out to identify emerging themes.

\section{Results and Discussion}

\subsection{Findings}

\section{The Participants' Characteristics}

Below is the table explaining the demographic of the participants.

Table 1. Demographic Information of the Participants

\begin{tabular}{cccc}
\hline & & $\begin{array}{c}\text { Number of } \\
\text { Preservice Teachers }\end{array}$ & $\begin{array}{c}\text { Number of } \\
\text { In-service Teachers }\end{array}$ \\
\hline Gender & Male & $11(31.43 \%)$ & 8 \\
& Female & $24(68.57 \%)$ & 10 \\
Age & $18-24$ & 32 & 6 \\
& $25-34$ & 3 & 12 \\
Years of Teaching & $<1$ year & 35 (during teaching practice) & 5 \\
Experience & 1 to 3 years & & 10 \\
& 3 to 5 years & & 3 \\
\cline { 2 - 4 } & &
\end{tabular}

It is shown from Table 1 that the number of female preservice teachers is more than twice the number of male preservice teachers. Meanwhile, the number of female teachers is just a little above their male colleagues for in-service teachers. For the age range, as typical for the university students, most of the preservice teachers are $18-24$, while for the second group, twothirds of the subjects are 25 to 34 years old. As for the teaching experience, all the pre-service teachers have only had experience teaching practice in secondary schools, while the in-service teachers mostly have had 1 to 3 years of teaching experience.

\section{Descriptive statistics for mathematics teaching efficacy score}

The following is the summary of the descriptive statistics from the data analysis of mathematics teaching efficacy scores.

Table 2. Descriptive Statistics for Mathematics Teaching Efficacy score

\begin{tabular}{ccc}
\hline Descriptive Statistics & Preservice Teachers & In-service Teachers \\
\hline Mean & 79.371 & 80.50 \\
Std. Deviation & 5.347 & 6.537 \\
Minimum & 70 & 69 \\
Maximum & 89 & 92 \\
Range & 19 & 23 \\
\hline
\end{tabular}

Table 2 shows that the in-service teachers score higher on average in teaching efficacy than the preservice teachers, 80.50 compared to 79.371 but having a more significant standard deviation. It descriptively shows that the teaching efficacy level of in-service teachers is higher than their juniors who are still in their teacher preparation program. 
However, the score variation in the in-service teacher's group is more noticeable, as indicated by the scores' more considerable range and higher standard deviation.

\section{Classification of Mathematics Teaching Efficacy Level}

The two analysis techniques were used to obtain the information on how the mathematics teaching efficacy scores fall into high, moderate, and low categories. The first was using criterion-referenced assessment through calculating the ideal mean (MI) and ideal standard deviation $(S D I)$ with a three-scale class. The purpose was to compare the level of teaching efficacy beliefs between the two groups of subjects. Furthermore, the second classification incorporated the norm-referenced assessment technique by comparing the scores within the groups with the five-scale category based on the group's mean $(\mu)$ and standard deviation $S D$ ). It was done to determine how the subjects' level of mathematics teaching efficacy beliefs varies within their respective groups.

Table 3. Classification of Mathematics Teaching Efficacy Level

\begin{tabular}{lcccccc}
\hline Criteria & Range of & \multicolumn{2}{c}{ Preservice Teachers } & \multicolumn{2}{c}{ Inservice Teachers } & Category \\
\cline { 3 - 6 } & Score & Number & Percentage & Number & Percentage & \\
\hline$x>M I+S D I$ & $x>77$ & 21 & 60 & 12 & 66.67 & High \\
$M I-S D I \leq x$ & $49 \leq x$ & 14 & 40 & 6 & 33.33 & Moderate \\
$\leq M I+S D I$ & $\leq 77$ & & & & & \\
$x<M I-S D I$ & $x<49$ & 0 & 0 & 0 & 0 & Low \\
\hline
\end{tabular}

Table 4. Within-Group Distribution of Mathematics Teaching Efficacy Level of Preservice Teachers

\begin{tabular}{|c|c|c|c|c|}
\hline Criteria & Range of Score & $\begin{array}{c}\text { Number of } \\
\text { Teachers }\end{array}$ & Percentage & Category \\
\hline$x \geq \mu+1.8 S D$ & $x \geq 88,9956$ & 1 & 2.86 & Very High \\
\hline $\begin{array}{l}\mu+0.6 S D \leq x \\
<\mu+1.8 S D\end{array}$ & $\begin{array}{l}82,5792 \leq x \\
<88,9956\end{array}$ & 10 & 28.58 & High \\
\hline $\begin{array}{l}\mu-0.6 S D \leq x \\
<\mu+0.6 S D\end{array}$ & $\begin{array}{l}76.1628 \leq x \\
<82,5792\end{array}$ & 13 & 37.15 & Moderate \\
\hline $\begin{array}{l}\mu-1.8 S D \leq x \\
<\mu-0.6 S D\end{array}$ & $\begin{array}{l}69.7464 \leq x \\
<76.1628\end{array}$ & 11 & 31.43 & Low \\
\hline$x<\mu-1.8 S D$ & $x<69.7464$ & 0 & 0 & Very Low \\
\hline
\end{tabular}

Table 5. Within-Group Distribution of Mathematics Teaching Efficacy Level of In-

\begin{tabular}{ccccc}
\multicolumn{4}{c}{ Service Teachers } & \\
\hline Criteria & Range of Score & $\begin{array}{c}\text { Number of } \\
\text { Teachers }\end{array}$ & Percentage & Category \\
\hline$x \geq \mu+1.8 S D$ & $x \geq 92,2671$ & 0 & 0 & Very High \\
& & & 33.33 & High \\
$\mu+0.6 S D \leq x<\mu+1.8 S D$ & $84,4224 \leq x<92,2671$ & 6 & 33.33 & Moderate \\
& & 6 & 33.33 & Low \\
$\mu-0.6 S D \leq x<\mu+0.6 S D$ & $76,5777 x<84,4224$ & 6 & 0 & Very Low \\
$\mu-1.8 S D \leq x<\mu-0.6 S D$ & $68.733 \leq x<76,5777$ & 0 & & \\
$x<\mu-1.8 S D$ & $x<68.733$ & & &
\end{tabular}


Table 3 shows that both groups' teaching efficacy level generally falls into moderate and higher categories. The majority of them, at least 60 per cent, is at a high level of efficacy. However, when looked into within-group variation, as in table 4 and table 5, it is shown that a significant number of subjects from both preservice and in-service teachers have low levels of mathematics teaching efficacy as compared to their colleagues. The percentage of teachers who have a low level of teaching efficacy is around 30 per cent for both the teacher candidates and the experienced teachers.

It is also interesting that only one teacher candidate, which makes slightly below 3 per cent of the preservice group, has a very high efficacy level, while none of the experienced teachers in the service group has this very high level. Interestingly, the percentage of participants with low, moderate, e and high teaching efficacy distributes evenly in the in-service teacher's group.

\section{Classification of PMTE MTOE Level of Efficacy}

As the MTEBI instrument consists of two subscales, the data analysis includes classifying the level of efficacy for Personal Mathematics Teaching Efficacy (PMTE) and Mathematics Teaching Outcome Expectancy (MTOE), which can be seen in the following tables.

Table 6. Classification of Personal Mathematics Teaching Efficacy (PMTE) Level

\begin{tabular}{lccccccl}
\hline Criteria & Range of & \multicolumn{2}{c}{ Preservice Teachers } & \multicolumn{2}{c}{ Inservice Teachers } & Category \\
\cline { 3 - 6 } & Score & Number & Percentage & Number & Percentage & \\
\hline$x>M I+S D I$ & $x>36.58$ & 35 & 100 & 18 & 100 & High \\
$M I-S D I \leq x$ & $28.42 \leq x$ & & & & & \\
$\leq M I+S D I$ & $\leq 36.58$ & 0 & 0 & 0 & 0 & Moderate \\
$x<M I-S D I$ & $x<28.42$ & 0 & 0 & 0 & 0 & Low \\
\hline
\end{tabular}

Table 6 above indicates that in terms of personal mathematics teaching efficacy, all the mathematics preservice and in-service teachers have a high level of efficacy, meaning both groups are confident with their capabilities to teach mathematics. Furthermore, when observed from the participants' expectancy of students' mathematics learning outcome, all of the teacher candidates have a high level of efficacy.

Meanwhile, nearly 90 per cent of the experienced teachers have the same high level of effectiveness, while the remaining teachers in the group have moderate efficacy levels. This data informs that in terms of students' mathematics learning outcomes, not all in-service teachers are as confident as their juniors who aspire to be mathematics teachers. The results can be seen in Table 7.

Table 7. Classification of Mathematics Teaching Efficacy Outcome Expectancy (MTOE) Level

\begin{tabular}{ccccccc}
\hline \multirow{2}{*}{ Criteria } & $\begin{array}{c}\text { Range of } \\
\text { Score }\end{array}$ & \multicolumn{2}{c}{ Preservice Teachers } & \multicolumn{2}{c}{ Inservice Teachers } & \multirow{2}{*}{ Category } \\
\cline { 3 - 6 } & Number & Percentage & Number & Percentage & \\
\hline$x>M I+S D I$ & $x>29.33$ & 35 & 100 & 16 & 88.89 & High \\
$M I-S D I \leq x$ & $18.67 \leq x$ & 0 & 0 & 2 & 11.11 & Moderate \\
$\leq M I+S D I$ & $\leq 29.33$ & 0 & 0 & 0 & 0 & Low \\
\hline$x<M I-S D I$ & $x<18.67$ & 0 & 0 & & &
\end{tabular}

As further looked in a more detailed analysis of the items for the PMTE and MTOE subscales, the item average and the total score average of both groups are as follows. 
Table 8. The Average Score for PMTE and MTOE Items

\begin{tabular}{lcccc}
\hline \multirow{2}{*}{ Subscales } & \multicolumn{2}{c}{ Preservice Teachers } & \multicolumn{2}{c}{ Inservice Teachers } \\
\cline { 2 - 5 } & $\begin{array}{c}\text { Item Average } \\
(\text { Mean })\end{array}$ & $\begin{array}{c}\text { Total Average } \\
(\text { Mean })\end{array}$ & $\begin{array}{c}\text { Item Average } \\
\text { (Mean })\end{array}$ & $\begin{array}{c}\text { Total Average } \\
\text { (Mean })\end{array}$ \\
\hline PMTE & 3.51 & 45.6 & 3.69 & 48.06 \\
MTOE & 4.22 & 33.77 & 4.06 & 32.44 \\
\hline
\end{tabular}

It is shown in the table that for the Personal Mathematics Teaching Efficacy (PMTE) subscale, both preservice and in-service teachers groups' answers for the items have the score of 3.51 and 3.69 on average, respectively. Generally, the participants from the two groups tend to have moderate to high efficacy levels for each item. Meanwhile, for the Mathematics Teaching Outcome Expectancy (MTOE) aspect, both groups score slightly above four (4) on average. It indicates that the participants tend to have high efficacy in this area and are generally somewhat higher than the other area. On the other hand, in terms of the total score average for both subscales, the in-service teachers score higher than the preservice teachers regarding personal teaching efficacy. In contrast, in-service teachers score below the other group in terms of outcome expectancy, but not significantly different.

\section{Inferential Statistics Results}

Analysis of the teaching efficacy scores of the two groups of respondents shows that the groups are normally distributed. It is indicated by the significant value $>0.05$, i.e. 0.231 for preservice teachers and 0.791 for in-service teachers. The variances of both classes are equal (homogenous) since the significance value 0.306 was greater than alpha 0.05 . The independent sample t-test was then also performed on the teaching efficacy scores to determine if there is a significant difference between the means of both groups. The result can be seen in the table below.

Table 9. Independent Sample t-test Result

\begin{tabular}{ccr}
\hline $\mathrm{t}$ & $\mathrm{df}$ & Sig. (2-tailed) \\
\hline 0.674 & 1 & 0,503 \\
\hline
\end{tabular}

The t-test result shows no significant difference between the level of mathematics teaching efficacy of both groups.

\section{Factors Affecting Teachers' Efficacy}

The interviews were also conducted with the participants from preservice and in-service teachers groups to seek possible factors affecting their efficacy beliefs. The results reveal that the teacher's mastery of content knowledge during the teacher preparation program and teaching experience is the contributing factor.

In terms of content knowledge, it is evident from the interview that the higher-performing teachers and teacher candidates show higher confidence levels regarding their teaching efficacy. They confidently mention their high grades during the teacher preparation program and relate the fact with their experience in teaching. The in-service math teachers acknowledge that they have no difficulties delivering the material and would always find the appropriate ways to teach complex math content, even if it is their first time teaching, including teaching practice. Meanwhile, the preservice teachers, although they only have a relatively short experience of teaching in schools, believe that they would be able to teach effectively and improve students' 
learning outcomes in the future. However, both groups also admit that they need to learn the math content before delivering it in the classroom.

On the other hand, the less performing teachers initially show hesitancy whether or not they would be able to teach effectively. However, as further revealed by the in-service teacher's group participants, after years of experience in teaching, they would finally be able to find the best method to teach. They admit that if they are not confident with their content knowledge, it will affect their teaching, by one of the teachers outlined as "confusing" and "less-prepared".

Furthermore, both groups also highlight the importance of learning and developing math learning media and technology skills, both conventional and digital, during the teacher preparation program. The in-service teachers, who felt better-prepared, are confident with their abilities with media and technology, although some rarely use it due to lack of facilities in schools. They also state that the curriculum provides the learning math media and technology as separate modules during the program. On the contrary, the teacher candidates, who follow the latest curriculum, which eliminates the specific module about math learning media and technology, feel less confident about their skills. Even though the curriculum integrates the media and technology in all other modules, they still need to learn it specifically in a separate module to enhance their skills fully.

Despite that, both groups agree that the teachers can majorly affect the students' mathematics learning outcomes. The teachers are confident that teachers' efforts influence the development of students' learning outcomes. It is especially evident when dealing with lessperforming students. But they also acknowledge some external factors that may affect the learning outcomes, such as peers and parents. They also note the internal factors such as students' motivation to learn and willingness to cooperate with what teachers have offered in class.

\subsection{Discussion}

The term mathematics teaching efficacy is often associated with the term mathematics teaching self-efficacy. Self-efficacy is an individual belief in achieving results under the expected goals [3, 4](Bandura, 1994; Bandura, 1997). Beliefs about self-efficacy determine how individuals feel, think, motivate themselves, and behave in various situations. The self-efficacy concept of Bandura [4] includes cognitive, social, emotional, and behavioural aspects that individuals must cultivate to achieve desired goals. Concerning mathematics teaching, selfefficacy is defined as the teacher's belief in his ability to carry out mathematics learning, improving student learning outcomes. Teacher self-efficacy is the teacher's belief in successfully organising and implementing the necessary programs to complete learning tasks. Bray-Clark and Bates [5] stated that teacher self-efficacy is the primary driver of a teacher's effectiveness and innovation in teaching.

Meanwhile, the research on teaching efficacy that is most frequently conducted is to measure the level of efficacy of student-teacher candidates (preservice teachers). Research with teachers (in-service teachers) does not seem to be the main subject of study for most researchers in teaching efficacy. It might be influenced by the perception of some experts that the formation of teaching efficacy belief mostly begins when a teacher is still learning to become a teacher, that is, by attending a teacher preparation/teacher education program. This belief will develop along with the increasing experience of students when they become teachers. Still, they do not change their initial beliefs because it is believed to be immune to change (resistant to change) [6]. 
The study results show no significant differences between the teaching efficacy beliefs between the mathematics teacher candidates and those already experienced in teaching. It is also revealed that the in-service teachers' teaching efficacy beliefs are already formed during their years in the teacher preparation program and only improve moderately after years of experience in teaching. However, the results are still in line with what Bray-Clark and Bates suggest that self-efficacy motivates the prospective and practicing math teachers' to improve their teaching skills in the future.

Although many studies related to teaching efficacy at the international level, many studies related to mathematics teaching efficacy are still limited. Through internet searching with the keywords teaching efficacy in Indonesia, only a few studies related to this topic are found. Research conducted by Pardimin [7] on the correlation between mathematics self-efficacy and mathematics teacher teaching efficacy. Another study was conducted by Dewanto [8] on the effectiveness of PPL on the self-efficacy of teaching mathematics education students. Individuals with high self-efficacy tend to show more effort than individuals with low levels of self-efficacy [7]. Self-efficacy affects individuals' mindset and emotional reactions, dealing with current situations and anticipating future conditions. Other studies have also shown that people with high self-efficacy will try harder to overcome the challenges they face [9].

Thus, a teacher or prospective mathematics teacher with high self-efficacy in teaching mathematics can theoretically strive for more effective and innovative learning for their students and face challenges during the teaching and learning process. It is evident from this study that the high-performing preservice and in-service math teachers tend to be more willing to innovate in their mathematics teaching to achieve expected results. This seems to be in accordance with the results of previous studies.

\section{Conclusion}

This study shows that the mathematics teaching efficacy beliefs of the preservice and inservice teachers are majorly firm or high in level, with no significant difference between groups. From the variation within the group results, most of the participants also have high levels of efficacy, with some falling into moderate and a fair amount in the low category. The analysis based on each subscale, Personal Mathematics Teaching Efficacy (PMTE) and the Mathematics Teaching Outcome Expectancy (MTOE), shows that the participants tend to have high efficacy in the MTOE aspect and generally slightly higher compared to the other aspect.

The key factors affecting the formation of such teaching efficacy beliefs are the teacher's mastery of content knowledge during the teacher preparation program and teaching experience. The higher-performing teachers and teacher candidates show higher confidence levels regarding their teaching efficacy, while the remaining teachers doubt their skills during their initial teaching experience. As further experienced, all the teachers and teacher candidates believe they would find the most effective way to teach mathematics.

As noted in the result that the teachers highlight the need to learn about math learning media and technology adequately, it is worth noting that teacher education programs prepare the teacher candidates with sufficient knowledge and skills. Appropriate measures regarding curriculum reformation will consequently be needed. 


\section{Acknowledgement}

The authors would like to thank LPPM UNIKA Santu Paulus Ruteng for funding this research. In particular, the authors would like to show gratitude to all the teachers and teacher candidates who are willing to take the time to become subjects in this research.

\section{References}

[1] Wenner, G.: Science and mathematics efficacy beliefs held by practising and prospective teachers: A 5-year study. Journal of Science Education and Technology, vol 10(2), pp. 181-187 (2001)

[2] Ryang, D.: Exploratory analysis of Korean elementary preservice teachers' mathematics teaching efficacy beliefs. International Electronic Journal of Mathematics Education, vol 7(2), pp. 45-61 (2007)

[3] Bandura, A.: Self-efficacy. In V. S. Ramachaudran (Ed.), Encyclopedia of human behavior vol. 4, pp. 71-81. Academic Press, New York (1994).

[4] Bandura, A.: Self-Efficacy: The exercise of control. Freeman, New York (1997).

[5] Bray-Clark, N. \& Bates, R.: Self-efficacy beliefs and teacher effectiveness: Implications for professional development. The Professional Educator, vol 16 (1), pp. 13-22 (2003)

[6] Moody, V. R. \& DuCloux, K. K.: Mathematics teaching efficacy among traditional and nontraditional elementary pre-service teachers. European Journal of Science and Mathematics Education, vol 3 (2), pp. 105-114 (2015)

[7] Pardimin.: Self-efficacy matematika dan self-efficacy mengajar matematika guru matematika. Jurnal Ilmu Pendidikan, vol 24 (1), pp. 29-37 (2018)

[8] Dewanto, A. C.: Efektivitas PPL untuk meningkatkan efikasi diri mengajar pada mahasiswa pendidikan matematika. Delta: Jurnal Ilmiah Pendidikan Matematika, vol 6 (1), pp. 1-9 (2018)

[9] Fitriana, S., Ihsan, H., \& Annas, S.: Pengaruh efikasi diri, aktivitas, kemandirian belajar dan kemampuan berpikir logis terhadap hasil belajar matematika pada siswa kelas VIII SMP. Journal of Educational Science and Technology, vol 1(2), pp. 86-101 (2015)

[10] Rahayu, L. P., Sartono, E. K. E., \& Miftakhuddin: Self-efficacy of primary school teachers in mathematics teaching: a comparative research on teacher training program products. Mimbar Sekolah Dasar, vol. 6(1), pp. 68-78 (2019)

[11] Unsal, S., Korkmaz, F., \& Percin, S.: Analysis of mathematics teachers' self-efficacy levels concerning the teaching process. Journal of Education and Practice, vol 7(24), pp. 99-107 (2016) 